\title{
Novel anti-inflammatory actions of TIPE2 in human primary amnion and myometrial cells
}

\author{
Ratana Lim ${ }^{1,2}$ and Martha Lappas ${ }^{1,2}$ \\ ${ }^{1}$ Mercy Perinatal Research Centre, Mercy Hospital for Women, Heidelberg, Victoria, Australia and ${ }^{2}$ Obstetrics, \\ Nutrition and Endocrinology Group, Department of Obstetrics and Gynaecology, University of Melbourne, \\ Victoria, Australia
}

Correspondence should be addressed to M Lappas; Email: mlappas@unimelb.edu.au

\begin{abstract}
Inflammation plays a pivotal role in the terminal process of human labor and delivery, including myometrial contractions and membrane rupture. TNF-alpha-induced protein 8-like-2 (TIPE2) is a novel inflammation regulator; however, there are no studies on the role of TIPE2 in human labor. We report that in myometrium, there is decreased TIPE2 mRNA expression during late gestation which was further decreased in labor. In fetal membranes, TIPE2 mRNA expression was decreased with both term and preterm labor compared to no labor samples. Knockdown of TIPE2 by siRNA in primary myometrium and amnion cells was associated with an augmentation of IL1B and TNF-induced expression of pro-inflammatory cytokines and chemokines; expression of contractionassociated proteins and secretion of the uterotonic prostaglandin PGF $_{2 \alpha}$ and expression of extracellular matrix degrading enzymes. In TIPE2-deficient myometrial cells treated with inhibitors of NF-KB or ERK1/2, the secretion of pro-labor mediators was reduced back to control levels. In conclusion, these in vitro experiments indicate that loss of TIPE2 exacerbates the inflammatory response.

Reproduction (2019) 158 95-107
\end{abstract}

\section{Introduction}

Preterm birth continues to be the main causation of neonatal morbidity and mortality (Blencowe et al. 2013). The dearth of effective strategies for idiopathic preterm labor currently in effect is due to only partial knowledge of the underlying mechanisms that drive human labor and delivery. It is widely recognized that inflammation contributes to the processes of human labor and delivery (Christiaens et al. 2008, Shynlova et al. 2013). Activation of the maternal immune system can occur physiologically (at term) or pathologically (at preterm) to induce an influx of inflammatory cells into fetal membranes, placenta and uterus (Thomson et al. 1999, Osman et al. 2003). Interleukin 1 beta (IL1B) and tumor necrosis factor alpha (TNF) are two pro-inflammatory cytokines that are secreted by activated leukocytes. They activate the pro-inflammatory transcription factor nuclear factor kappa B (NF-kB) (Lappas et al. 2002, 2003, Lindstrom \& Bennett 2005, Lappas \& Rice 2007) and mitogen-activated protein kinases (MAPKs) (Sooranna et al. 2005, Lappas et al. 2007, 2011b) to regulate the expression of many genes involved in the terminal effector pathways of human labor and delivery in myometrium and fetal membranes. These include, the pro-inflammatory cytokines TNF, IL1A, IL1B and IL6, the chemokines CCL2, CXCL1 and CXCL8, contractionassociated proteins such as prostaglandin-endoperoxide synthase 2 (PTGS2), prostaglandin $\mathrm{F}$ receptor (PTGFR), connexin $43(\mathrm{Cx} 43)$ and the oxytocin receptor (OXTR) and extracellular matrix-(ECM) degrading enzymes such as matrix metalloproteinase 9 (MMP9).

TNF-alpha-induced protein 8-like-2 (TNFAIP8L2 or TIPE2), a member of the TNFAIP8/TIPE family, negatively regulates inflammation (Sun et al. 2008, Lou et al. 2013, Goldsmith \& Chen 2017, Lin et al. 2018). TIPE2 was originally identified in lymphoid tissues in mice (Sun et al. 2008); however, human TIPE2 is more widely expressed in a wide variety of hematopoietic and non-hematopoietic cell types (Zhang et al. 2011). TIPE2 has a distinct death effector domain-like domain that is essential for maintaining innate and adaptive immune homeostasis (Freundt et al. 2008, Sun et al. 2008). Deletion of TIPE2 in mice leads to multiorgan inflammation, splenomegaly, premature death and hypersensitivity to inflammatory insults (Sun et al. 2008, 2012). Likewise, knockdown of TIPE2 augments the expression of pro-inflammatory cytokines, chemokines and ECM-degrading enzymes in response to various inflammatory insults (Lou et al. 2013, Suo et al. 2016, Sun et al. 2017a, Zhang et al. 2017, Lin et al. 2018). Conversely, TIPE2 overexpression suppresses the expression of these inflammatory genes (Zhang et al. 2015, Sun et al. 2017a, Lin et al. 2018). Emerging evidence suggests that TIPE2 negatively regulates inflammation by inhibiting the activation of NF-KB (Sun 
et al. 2008, Lou et al. 2013, Goldsmith \& Chen 2017, Lin et al. 2018) and MAPK (Sun et al. 2008, Lou et al. 2013, Zhang et al. 2017, Lin et al. 2018).

The expression of TIPE2 is downregulated in a number of diverse immunological diseases including cancer (Gus-Brautbar et al. 2012), systemic lupus erythematosus (Li et al. 2009), diabetic nephropathy (Zhang et al. 2010), hepatitis B virus infection (Xi et al. 2011), respiratory infection (Zhang et al. 2017), asthma (Ma et al. 2013, Sun et al. 2017a), atherosclerosis (Lou et al. 2013) and colitis (Lou et al. 2014). With respect to pregnancy, TIPE2 expression is lower in decidual tissues of patients with missed abortion than healthy controls (Sun et al. 2017b). There are, however, no studies on the role of TIPE2 in human labor. To address this issue, we characterized TIPE2 expression in human myometrium and fetal membranes from laboring and non-laboring women and examined the effects of TIPE2 knockdown on pro-inflammatory and pro-labor mediators. For the functional studies we used IL1B and TNF as these are the two pro-inflammatory cytokines that play critical roles in stimulating pro-inflammatory and pro-labor mediators (Lappas 2017, Lim et al. 2017). Notably, they have also been shown to induce preterm labor in various animal species (Romero et al. 1991, Sadowsky et al. 2006).

\section{Materials and methods}

\section{Tissue collection}

Placenta (with attached fetal membranes) and myometrium were obtained, with Institutional Research and Ethics Committee approval, from women at the time of delivery. All women provided written informed consent. Exclusion criteria included women with any underlying medical conditions such as diabetes, asthma, polycystic ovary syndrome, preeclampsia and macrovascular complications, multiple pregnancies and obese women (BMI > 30).

Myometrium was obtained from the upper margin of the lower uterine segment incision during Cesarean section.
Placenta and myometrium was brought to the research laboratory and processed within $15 \mathrm{~min}$ of delivery. Fetal membranes were removed from placenta, washed extensively in PBS and then dissected into smaller pieces. Tissues were immediately snap frozen in liquid nitrogen and stored at $-80^{\circ} \mathrm{C}$ for expression studies or used immediately for cell culture experiments.

To characterize temporal-associated changes in TIPE2 expression, myometrium and fetal membranes were obtained from women at preterm ( $<37$ week gestation) or term (37-41 weeks gestation) Cesarean section in the absence of labor ( $n=9$ patients per group). In the term group, indications for Cesarean section in the absence of labor were breech presentation and/or previous Cesarean section. In the preterm group, indications for Cesarean section in the absence of labor were placenta praevia, placental abruption and antepartum hemorrhage. The relevant clinical characteristics of the patients used are detailed in Table 1.

To characterize labor-associated changes in TIPE2 expression in myometrium, samples were obtained from women at term Cesarean section (i) in the absence of labor or (ii) during active spontaneous labor $(n=8$ patients per group) as previously described (Lim et al. 2018). Labor was defined as the presence of regular uterine contractions (every 3-4 min) resulting in cervical effacement and dilation. None of the patients received any medications to augment or induce labor. Indications for Cesarean section in the absence of labor were breech presentation and/or previous Cesarean section. Indications for Cesarean section in the laboring samples were for fetal malpresentation, fetal distress and delayed or failure to progress. The relevant clinical characteristics of the patients used are detailed in Table 2.

To characterize labor-associated changes in TIPE2 expression in fetal membranes, samples were obtained from women at preterm or term (i) undergoing elective Cesarean section in the absence of labor or (ii) after spontaneous labor and vaginal delivery ( $n=9$ patients per group). Fetal membranes from the non-laboring group were obtained from the area overlying the cervix (i.e. supracervical site, SCS) as previously described (Lappas et al. 2011a). In the after labor group, fetal membranes were obtained from the

Table 1 Clinical characteristics of the patients used for temporal-associated changes in TIPE2.

\begin{tabular}{|c|c|c|c|c|}
\hline & \multicolumn{2}{|c|}{ Fetal membranes } & \multicolumn{2}{|c|}{ Myometrium } \\
\hline & Preterm $(n=9)$ & Term $(n=9)$ & Preterm $(n=9)$ & Term $(n=9)$ \\
\hline Maternal age (years) & $32.3(2.33)$ & $30.6(2.1)$ & $32.7(1.6)$ & $31.6(1.5)$ \\
\hline Pre-pregnancy maternal BMI & $23.5(1.8)$ & $24.2(1.6)$ & $21.8(0.9)$ & $23.5(1.2)$ \\
\hline Gravida & $2.6(0.6)$ & $3.6(0.7)$ & $2.0(0.2)$ & $2.1(0.2)$ \\
\hline Parity & $2.0(0.4)$ & $2.7(0.4)$ & $1.6(0.2)$ & $2.0(0.2)$ \\
\hline Gestational age (weeks) & $33.3(0.8)$ & $39.3(0.3)^{*}$ & $34.4(0.2)$ & $38.8(0.2)^{*}$ \\
\hline Fetal gender & 5 female; 4 male & 5 female; 4 male & 7 female; 2 male & 2 female; 7 male \\
\hline Birthweight (g) & $1647(252)$ & $3429(120)^{*}$ & $2156(124)$ & $3416(148)^{*}$ \\
\hline \multicolumn{5}{|l|}{ Labor } \\
\hline No labor (\%) & 100 & 100 & 100 & 100 \\
\hline Spontaneous (\%) & 0 & 0 & 0 & 0 \\
\hline \multicolumn{5}{|l|}{ Membrane Rupture } \\
\hline SROM (\%) & 0 & 0 & 0 & 0 \\
\hline ARM $(\%)$ & 100 & 100 & 100 & 100 \\
\hline
\end{tabular}

Values represent mean ( \pm S.E.M.) unless otherwise specified.

$* P<0.05$ vs preterm (Student's $t$-test). 
Table 2 Clinical characteristics of the patients used for term labor-associated changes in TIPE2.

\begin{tabular}{|c|c|c|c|c|}
\hline & \multicolumn{2}{|c|}{ Fetal membranes } & \multicolumn{2}{|c|}{ Myometrium } \\
\hline & Term no labor $(n=9)$ & Term after labor $(n=9)$ & Term no labor $(n=8)$ & Term in labor $(n=8)$ \\
\hline Maternal Age (years) & $30.6(2.1)$ & $29(2.3)$ & $32.9(1.3)$ & $31.5(1.6)$ \\
\hline Pre-pregnancy maternal BMI & $24.2(1.6)$ & $24.1(1.2)$ & $22.6(1.1)$ & $22.4(1.0)$ \\
\hline Gravida & $3.6(0.7)$ & $2.8(0.6)$ & $2.6(0.3)$ & $2.0(0.4)$ \\
\hline Parity & $2.3(0.2)$ & $1.6(0.3)$ & $1.3(0.2)$ & $0.5(0.3)$ \\
\hline Gestational age (weeks) & $39.3(0.3)$ & $40.4(0.2)$ & $38.9(0.2)$ & $39.6(0.5)$ \\
\hline Fetal gender & 5 female; 4 male & 2 female; 7 male & 4 female; 4 male & 3 female; 5 male \\
\hline Birthweight (g) & $3429(120)$ & $3466(133)$ & $3318(216)$ & $3582(77)$ \\
\hline \multicolumn{5}{|l|}{ Labor } \\
\hline No labor & $100 \%$ & $0 \%$ & $100 \%$ & $0 \%$ \\
\hline Spontaneous & $0 \%$ & $100 \%$ & $0 \%$ & $100 \%$ \\
\hline Duration of labor (min) & $\mathrm{N} / \mathrm{A}$ & $511(127)$ & $\mathrm{N} / \mathrm{A}$ & $668(90)$ \\
\hline \multicolumn{5}{|l|}{ Membrane Rupture } \\
\hline SROM & $0 \%$ & $100 \%$ & $0 \%$ & $12.5 \%$ \\
\hline PROM & $0 \%$ & $0 \%$ & $0 \%$ & $25 \%$ \\
\hline ARM & $100 \%$ & $0 \%$ & $100 \%$ & $62.5 \%$ \\
\hline
\end{tabular}

Values represent mean ( \pm S.E.M.) unless otherwise specified.

site of membrane rupture as previously described (Lappas et al. 2011a). None of the patients received any medications to augment or induce labor or had prelabor rupture of membranes. The relevant clinical characteristics of the patients used are detailed in Tables 2 and 3 .

\section{Primary myometrial and amnion epithelial and mesenchymal cell culture}

Fresh myometrium and amnion were obtained from women who delivered healthy, singleton infants at term undergoing elective Cesarean section in the absence of labor $(n=6-8$ patients). Myometrial cells were isolated and cultured as previously described (Lim et al. 2013a). Isolation of amnion epithelial cells and mesenchymal cells was performed as described (Moore et al. 2009) with minor modifications. Briefly, approximately $3 \mathrm{~g}$ of amnion fragments were incubated in $10 \mathrm{~mL}$ of DMEM/F-12 with $1 \%$ penicillin-streptomycin and $0.25 \%$ trypsin for $35 \mathrm{~min}$ at $37^{\circ} \mathrm{C}$ with gentle agitation. After straining through a $100 \mu \mathrm{m}$ cell strainer, the eluate was neutralized with $1 \%$ FBS and remaining fragments were further digested in another $10 \mathrm{~mL}$ of DMEM/F-12 with $0.25 \%$ trypsin for $35 \mathrm{~min}$ at $37^{\circ} \mathrm{C}$. Eluate was combined with previous digest and epithelial cells were pelleted by centrifugation at $500 \mathrm{~g}$ for $10 \mathrm{~min}$, resuspended in complete media (DMEM/F-12 containing $10 \%$ FBS and $1 \%$ penicillin-streptomycin) and plated in tissue culture flasks. Flasks were incubated at $37^{\circ} \mathrm{C}$, $5 \% \mathrm{CO}_{2}$ and $8 \% \mathrm{O}_{2}$ with media changes $4 \mathrm{~h}$ after initial plating, and then $24-48 \mathrm{~h}$ thereafter until confluent. The de-epithelialized amnion fragments were washed extensively in PBS and then incubated in $10 \mathrm{~mL}$ DMEM/F-12 containing $1 \%$ penicillin-streptomycin and $0.125 \%$ collagenase $A$ at $37^{\circ} \mathrm{C}$ for $1 \mathrm{~h}$ with gentle agitation, until fragments had dissolved. After straining, eluate was centrifuged at $500 \mathrm{~g}$ for $10 \mathrm{~min}$. Pelleted mesenchymal cells were plated in complete media (DMEM/F-12 containing 10\% FBS and 1\% penicillinstreptomycin) in tissue culture flasks. Upon confluency (3-5 days), epithelial and mesenchymal cells were trypsinized and plated in 48-well plates in complete media for siRNA transfection experiments.

\section{Transfection of primary myometrial and amnion cells}

Transfection of myometrial and amnion cells with TIPE2 siRNA (siTIPE2; Ambion (Thermo Fisher Scientific)) or negative control siRNA (siCONT; Ambion (Thermo Fisher Scientific)) was performed using RNAiMax (Life Technologies) according to manufacturer's guidelines. Myometrial cells ( $n=8$ patients), amnion mesenchymal cells ( $n=6$ patients) and amnion epithelial cells ( $n=6$ patients) were transfected with $25 \mathrm{nM}$ siTIPE2 or $25 \mathrm{nM}$ siCONT for $48 \mathrm{~h}$, followed by treatment with $1 \mathrm{ng} / \mathrm{mL}$ IL1B or $10 \mathrm{ng} / \mathrm{mL}$ TNF for an additional $20 \mathrm{~h}$. Myometrial cells ( $n=5$ patients) were also transfected with $25 \mathrm{nM}$ (equivalent to $83 \mathrm{ng}$ ) siTIPE2 or $25 \mathrm{nM}$ (83 ng) siCONT for $48 \mathrm{~h}$, followed by treatment with $1 \mathrm{ng} / \mathrm{mL}$ IL1B

Table 3 Clinical characteristics of the patients used for preterm labor-associated changes in TIPE2.

\begin{tabular}{lcc}
\hline & \multicolumn{2}{c}{ Fetal membranes } \\
\cline { 2 - 3 } & $\begin{array}{c}\text { Preterm no labor } \\
(n=9)\end{array}$ & $\begin{array}{c}\text { Preterm after labor } \\
(n=9)\end{array}$ \\
\hline Maternal age (years) & $32.3(2.3)$ & $33.1(0.8)$ \\
Pre-pregnancy maternal & $23.5(1.8)$ & $25.0(1.5)$ \\
BMI & & \\
Gravida & $2.6(0.6)$ & $2.6(0.6)$ \\
Parity & $2.0(0.4)$ & $1.6(0.2)$ \\
Gestational age (weeks) & $33.3(0.8)$ & $33.6(0.7)$ \\
Fetal gender & 5 female; 4 male & 2 female; 7 male \\
Birthweight (g) & $1647(252)$ & $1859(177)$ \\
Delivery mode & & \\
$\quad$ Vaginal delivery & $0 \%$ & $100 \%$ \\
Cesarean section & $100 \%$ & $0 \%$ \\
Labor & & \\
$\quad$ No labor & $100 \%$ & $0 \%$ \\
Spontaneous & $0 \%$ & $357(92)$ \\
$\quad$ Duration of labor (min) & $\mathrm{N} / \mathrm{A}$ & \\
Membrane Rupture & & $44.4 \%$ \\
$\quad$ SROM & $0 \%$ & $0 \%$ \\
PROM & $0 \%$ & $77.8 \%$ \\
$\quad$ ARM & $100 \%$ & \\
Steroids & $100 \%$ & \\
\hline Valu & &
\end{tabular}

Values represent mean ( \pm S.E.M.) unless otherwise specified. 
in the absence or presence of $10 \mu \mathrm{M}$ BAY 11-7082, $5 \mu \mathrm{M}$ $\cup 0126$ or $400 \mu \mathrm{M}$ naringenin for an additional $20 \mathrm{~h}$. After final incubation, cells were collected and stored at $-80^{\circ} \mathrm{C}$ until assayed for mRNA expression by qRT-PCR and protein expression by Western blotting as detailed below. Media was collected and stored at $-80^{\circ} \mathrm{C}$ until assayed for cytokine and prostaglandin release as detailed below. Cell viability was assessed by the 3-(4,5-dimethyl-2-thiazolyl)-2,5-diphenyl$2 \mathrm{H}$-tetrazolium bromide (MTT) proliferation assay as we have previously described (Lim et al. 2014).

\section{RNA extraction and $q R T-P C R$}

RNA extractions, cDNA synthesis and qRT-PCR were performed as previously described (Lim et al. 2013b) using $100 \mathrm{nM}$ of pre-designed and validated QuantiTect primers (primer sequences not available) (Qiagen). Target gene $\mathrm{Ct}$ values were normalized to the average $\mathrm{YWHAZ}$ and succinate dehydrogenase (SDHA) Ct values of the same cDNA sample and fold differences determined using the comparative $\mathrm{Ct}$ method. Of note, there was no effect of treatment on YWHAZ or SDHA Ct values.

\section{Cytokine and prostaglandin assays}

The levels of IL6, CCL2, CXCL1 and CXCL8 in the incubation media was measured by sandwich ELISA from R\&D Systems according to the manufacturer's instructions. The release of PGF $_{2 \alpha}$ into the incubation medium was assayed using a commercially available competitive enzyme immunoassay kit according to the manufacturer's specifications (Cayman Chemical Company). The interassay and intraassay coefficients of variation for all assays were less than $10 \%$.

\section{Gelatin zymography}

Incubation media were also collected and assessment of MMP9 was performed by gelatin zymography as previously described (Lim et al. 2013b). Gels were scanned using a ChemiDoc XRS system (Bio-Rad Laboratories), inverted and densitometry performed using Quantity One image analysis software (Bio-Rad Laboratories).

\section{Statistical analysis}

All statistical analyses were undertaken using GraphPad Prism (GraphPad Software). Normality of the data was assessed using the Shapiro-Wilk test. For two sample comparisons, unpaired Student's t-test was used to assess the statistical significance between normally distributed data; otherwise, the nonparametric Mann-Whitney $U$ (unpaired) test was used. For all other comparisons, non-normalized data were logarithmically transformed before analysis by a repeatedmeasures one-way ANOVA (with LSD post hoc testing to discriminate among the means). Statistical significance was ascribed to a $P$ value $\leq 0.05$. Data are expressed as mean \pm S.E.M.

\section{Results}

\section{Temporal and labor-associated changes in TIPE2 expression in myometrium and fetal membranes}

As shown in Fig. 1A, in myometrium collected from women in the absence of labor, there was a significant decrease in TIPE2 mRNA expression in myometrium from women at term compared to preterm gestation. Fig. 1B demonstrates that at term, there is a significant decrease in TIPE2 mRNA expression in myometrium collected in labor compared to myometrium collected before the onset of labor. In fetal membranes, there was no change in TIPE2 mRNA expression with regards
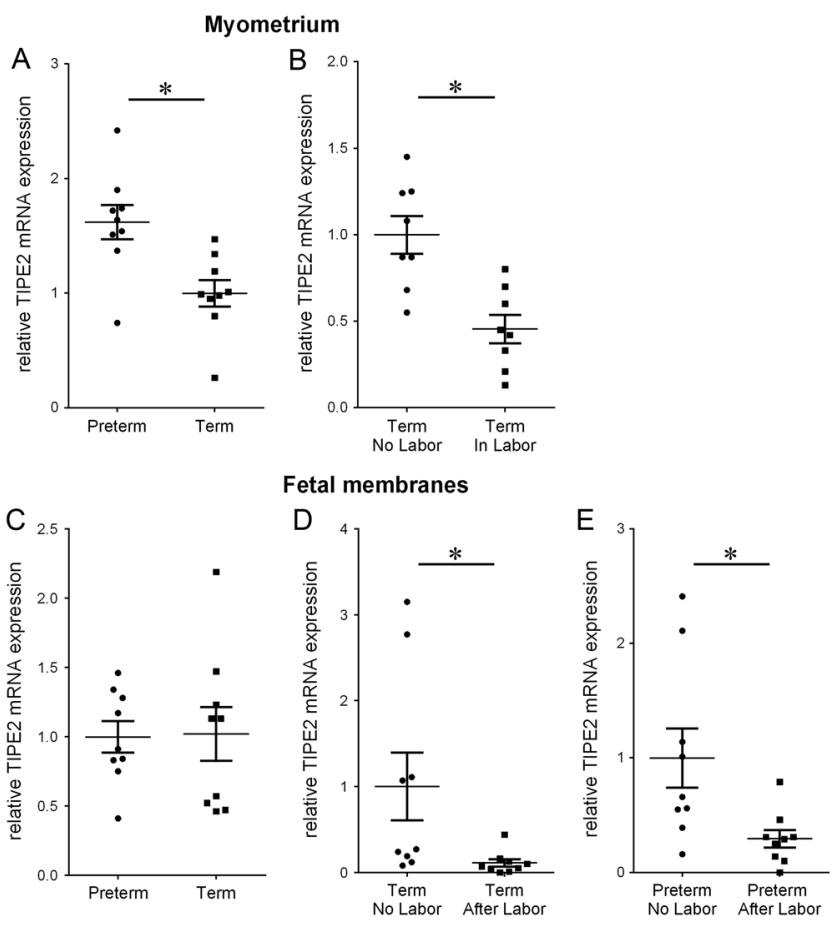

Figure 1 Temporal and labor-associated changes in TIPE2 expression in myometrium and fetal membranes. (A) Myometrium was obtained from women at preterm Cesarean section in the absence of labor (preterm, $n=9$ patients) or from women at term Cesarean section in the absence of labor (term, $n=9$ patients). (B) Myometrium was obtained from women at term Cesarean section in the absence of labor (term no labor, $n=8$ patients) or from women at term Cesarean section during labor (term in labor, $n=8$ patients). (C) Fetal membranes were obtained from women at preterm Cesarean section in the absence of labor (preterm, $n=9$ patients) or from women at term Cesarean section in the absence of labor (term, $n=9$ patients). (D) Fetal membranes were obtained from women at term Cesarean section in the absence of labor (term no labor, $n=9$ patients) or from women after term spontaneous labor onset and delivery (term after labor, $n=9$ patients). (E) Fetal membranes were obtained from women at preterm Cesarean section in the absence of labor (preterm no labor, $n=9$ patients) or from women after preterm spontaneous labor onset and delivery (preterm after labor, $n=9$ patients). TIPE2 mRNA expression was analyzed by qRT-PCR. Individual data points represent different patients and the horizontal line represents the mean \pm S.E.M. of each group. ${ }^{*} P \leq 0.05$, unpaired Student's $t$-test (panels A, B and C) or Mann-Whitney $U$ test (panels D and E). 
to term or preterm gestation (Fig. 1C). On the other hand, there were significant decreases in TIPE2 mRNA expression after spontaneous labor and delivery at both term (Fig. 1D) and preterm (Fig. 1E) gestations when compared to non-laboring samples.

\section{Effect of TIPE2 on pro-inflammatory cytokines and chemokines in human primary myometrial and amnion cells}

To determine if TIPE2 regulates cytokine-induced expression of pro-labor mediators, primary cells isolated from human myometrium and amnion (epithelial and mesenchymal cells) were transfected with TIPE2 siRNA (siTIPE2). The efficacy of siTIPE2 transfection was assessed by qRT-PCR. When compared to siCONT-transfected cells, TIPE2 mRNA expression was significantly decreased in siTIPE2 transfected myometrial cells $(82 \%$ decrease), amnion mesenchymal cells (76\% decrease) and amnion epithelial cells ( $83 \%$ decrease). There was no effect of siTIPE2 on cell viability as determined by MTT cell viability assay (data not shown).

Figure 2 demonstrates the effect of siTIPE2 transfection on IL1B and TNF induced proinflammatory cytokines in myometrial cells and amnion mesenchymal cells. Table 4 demonstrates the effect of siTIPE2 transfection on TNF-induced proinflammatory cytokines in amnion epithelial cells. In myometrial cells and amnion mesenchymal cells, there was an expected increase in ILIA and IL6 mRNA expression and release of IL6 in siCONT-transfected cells treated with IL1B and an increase in IL1A, ILIB and IL6 mRNA expression and release of IL6 in siCONT cells treated with TNF (Fig. 2A, B, C, D, E, F and $\mathrm{G}$ for myometrium, Fig. $2 \mathrm{H}, \mathrm{I}, \mathrm{J}, \mathrm{K}, \mathrm{L}, \mathrm{M}$ and $\mathrm{N}$ for amnion mesenchymal cells). Likewise, in siCONTtransfected amnion epithelial cells, TNF induced significant increases in IL1A and IL6 mRNA expression and release of IL6. In myometrial cells, there was a significant increase in ILIA and IL6 mRNA expression and release of IL6 in siTIPE2-transfected myometrial cells treated with IL1B, compared to IL1B-treated siCONT-transfected cells (Fig. 2A, B and C). There was also an increase in ILIA and IL1B mRNA expression in TNF-stimulated siTIPE2-transfected cells (Fig. 2D and E); however, there was no effect of siTIPE2 on TNFinduced IL6 mRNA expression and secretion (Fig. 2F and G). Similar results were obtained in amnion mesenchymal and epithelial cells, where siTIPE2transfected cells significantly increased IL1B-induced ILIA and IL6 mRNA expression and IL6 secretion (Fig. $2 \mathrm{H}, \mathrm{I}, \mathrm{J}$ and Table 4) and TNF-induced IL1A and IL1B mRNA expression (Fig. $2 \mathrm{~K}, \mathrm{~L}$ and Table 4); there was no effect of siTIPE2 on TNF-induced IL6 mRNA expression and secretion (Fig. 2M, N and Table 4).

Figure 3 depicts the effect of siTIPE2 on chemokine expression and secretion in myometrium cells. Treatment of siCONT-transfected cells with both IL1B and TNF
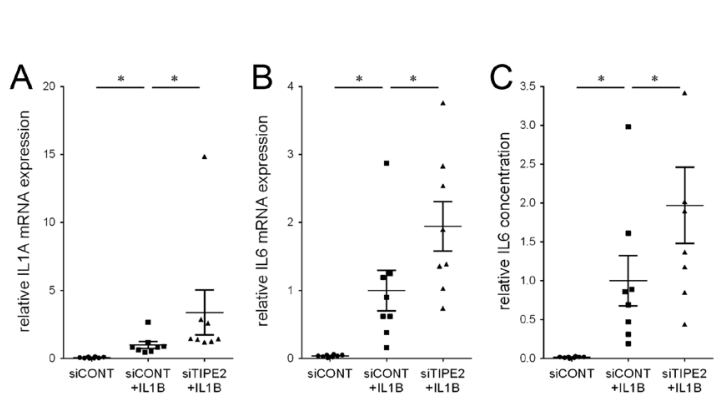

Myometrial cells
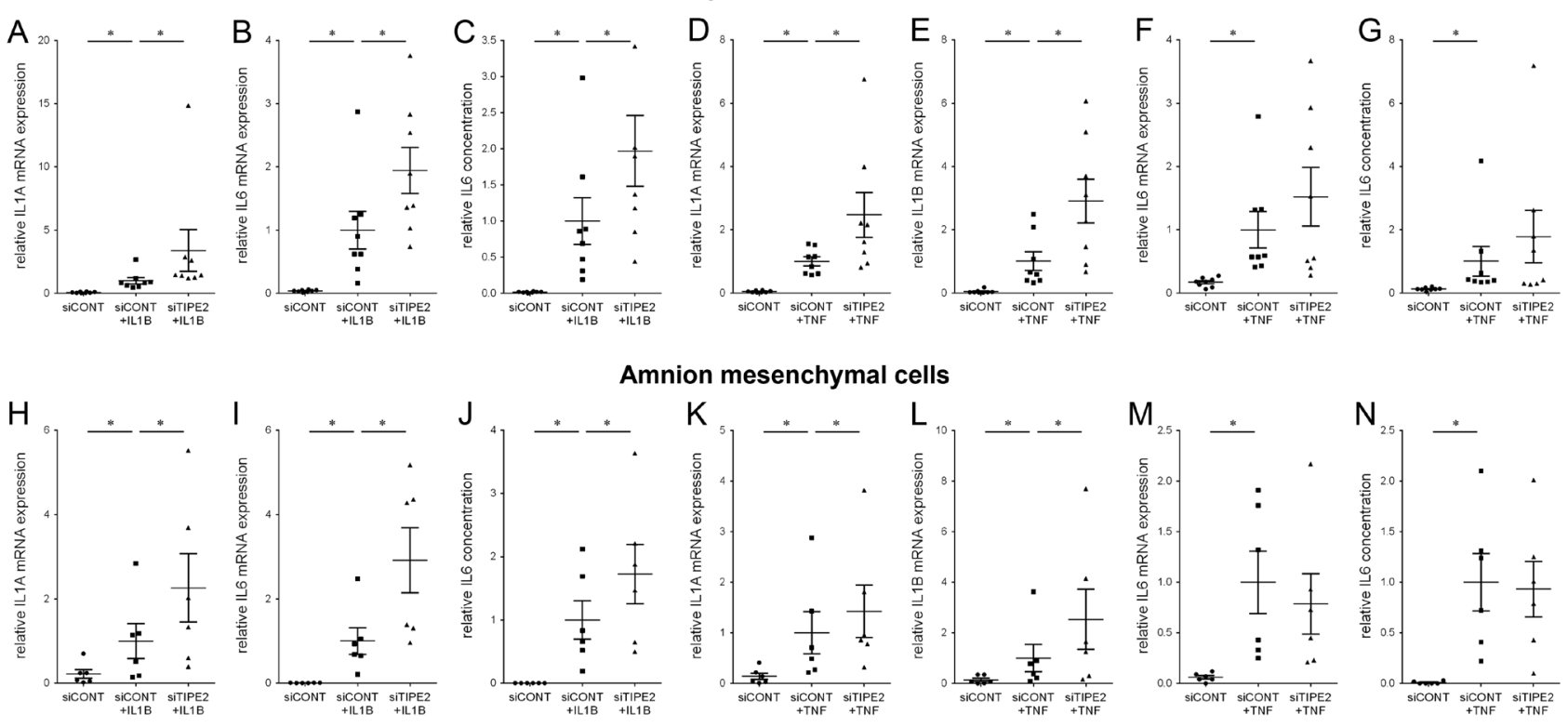

\section{Amnion mesenchymal cells}
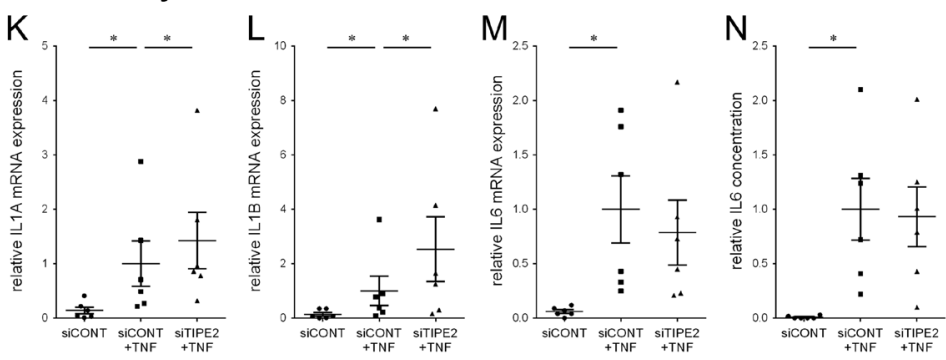

Figure 2 Effect of TIPE2 siRNA transfection on pro-inflammatory cytokines in myometrial and amnion mesenchymal cells. (A, B, C, D, E, F and G) Human primary myometrial cells or ( $\mathrm{H}, \mathrm{I}, \mathrm{J}, \mathrm{K}, \mathrm{L}, \mathrm{M}$ and $\mathrm{N}$ ) amnion mesenchymal cells were transfected with $25 \mathrm{nM}$ siCONT or $25 \mathrm{nM}$ siTIPE2 and then treated with $1 \mathrm{ng} / \mathrm{mL}$ IL1B or $10 \mathrm{ng} / \mathrm{mL}$ TNF ( $n=6$ patients). (A, B, D, E, F, H, I, K, L and M) IL1A, IL1B and IL6 mRNA expression was analyzed by qRT-PCR. (C, G, J and N) The concentration of IL6 in the incubation medium was assayed by ELISA. For all data, the fold change was calculated relative to siCONT + IL1B- or siCONT + TNF-transfected cells and data displayed as mean \pm S.E.M. Individual data points represent six independent experiments. ${ }^{*} P \leq 0.05$ (repeated measures one-way ANOVA). 
Table 4 Effect of siTIPE2 on expression and secretion of pro-labor mediators in human primary amnion epithelial cells.

\begin{tabular}{|c|c|c|c|c|c|c|c|c|c|}
\hline & \multicolumn{5}{|c|}{ mRNA expression } & \multicolumn{4}{|c|}{ Secretion } \\
\hline & IL1A & IL6 & CCL2 & CXCL1 & CXCL8 & IL6 & CCL2 & CXCL1 & CXCL8 \\
\hline siCONT & $0.0 \pm 0.0^{*}$ & $0.0 \pm 0.0^{*}$ & $0.0 \pm 0.0^{*}$ & $0.0 \pm 0.0^{*}$ & $0.1 \pm 0.0^{*}$ & $0.0 \pm 0.0^{*}$ & $0.0 \pm 0.0^{*}$ & $0.01 \pm 0.0^{*}$ & $0.0 \pm 0.0^{*}$ \\
\hline siCONT+TNF & $1.0 \pm 0.2$ & $1.0 \pm 0.7$ & $1.0 \pm 0.2$ & $1.0 \pm 0.3$ & $1.0 \pm 0.3$ & $1.0 \pm 0.4$ & $1.0 \pm 0.3$ & $1.0 \pm 0.5$ & $1.0 \pm 0.2$ \\
\hline siTIPE2 + TNF & $1.8 \pm 0.4 *$ & $1.0 \pm 0.8$ & $1.1 \pm 0.3$ & $2.0 \pm 0.4^{*}$ & $2.0 \pm 0.5^{*}$ & $1.1 \pm 0.4$ & $1.1 \pm 0.5$ & $1.7 \pm 0.4^{*}$ & $1.6 \pm 0.3^{*}$ \\
\hline
\end{tabular}

For all data, the fold change was calculated relative to siCONT+TNF-transfected cells and data displayed as mean \pm S.E.M.

${ }^{*} P \leq 0.05$ vs siTIPE $2+$ TNF-transfected cells (repeated-measures one-way ANOVA).

significantly increased CCL2, CXCL1 and CXCL8 mRNA expression and secretion. There was no effect of siTIPE2 on CCL2 mRNA expression or secretion when treated with IL1B or TNF (Fig. 3A, B, G and H). In siTIPE2transfected cells there was a significant augmentation in both IL1B- and TNF-induced CXCL1 mRNA expression and secretion (Fig. 3C, D, I and J). In siTIPE2-transfected cells, there was a significant augmentation of CXCL8 mRNA expression when treated with both IL1B and TNF (Fig. 3E and $\mathrm{K}$ ); however, there was only a significant increase in CXCL8 secretion in siTIPE2 cells treated with TNF (Fig. 3L), not IL1B (Fig. 3F).

In amnion mesenchymal cells (Fig. 4), siTIPE2transfected cells significantly increased both IL1B- and TNF-induced CXCL1 and CXCL8 mRNA expression and secretion (Fig. 4C, D, E, F, I, J, K and L) and CCL2 secretion (Fig. 4B and $\mathrm{H}$ ). There was a significant increase IL1Binduced CCL2 mRNA expression in siTIPE2-transfected cells (Fig. 4A), but there was no change in TNF-induced
CCL2 mRNA expression (Fig. 4G). Similarly, in amnion epithelial cells (Table 4), the effect of siTIPE2 was a significant augmentation of TNF-induced CXCL1 and CXCL8 mRNA expression and CXCL1 and CXCL8 secretion. There was, however, no effect of siTIPE2 on TNF-induced CCL2 mRNA expression or CCL2 secretion.

The effect of siTIPE2 on the expression of pro-labor mediators, in the absence of inflammation, was also determined in myometrial cells, shown in Table 5 . Compared to siCONT-transfected cells, there was no effect of siTIPE2 transfection on cytokine and chemokine mRNA expression (TNF, IL1A, IL1B, IL6, CCL2, CXCL1 and CXCL8) or secretion (IL6, CCL2, CXCL1 and CXCL8).

\section{Effect of TIPE2 on expression of contraction-associated proteins in myometrium}

The effect of siTIPE2 on contraction-associated proteins and prostaglandins in myometrial cells is demonstrated

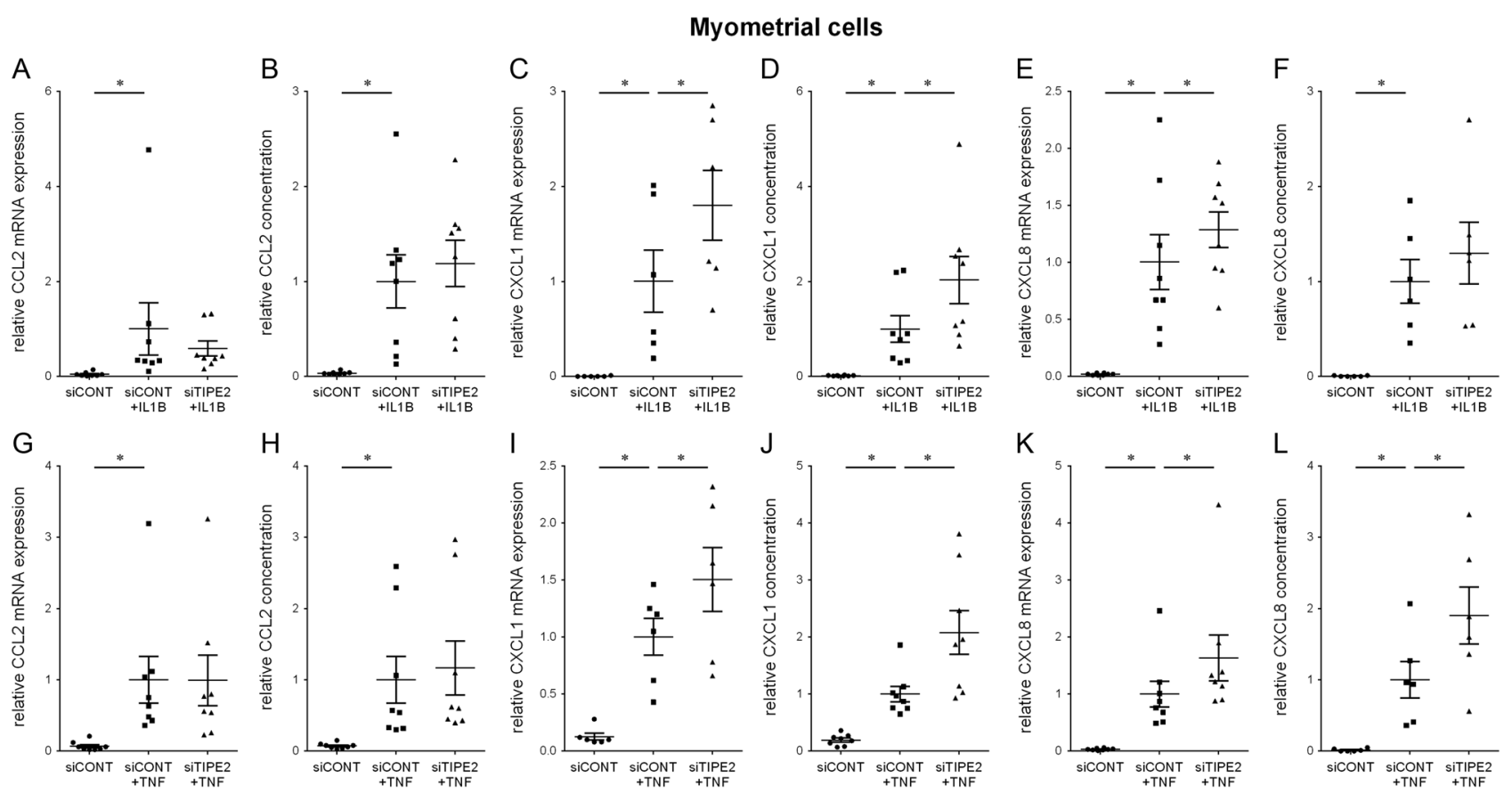

Figure 3 Effect of TIPE2 siRNA transfection on chemokines in myometrial cells. Human primary myometrial cells were transfected with $25 \mathrm{nM}$ siCONT or $25 \mathrm{nM}$ siTIPE2 and then treated with $1 \mathrm{ng} / \mathrm{mL}$ IL1B or $10 \mathrm{ng} / \mathrm{mL}$ TNF ( $n=6$ patients). (A, C, E, G, I and K) CCL2, CXCL1 and CXCL8 mRNA expression was analyzed by qRT-PCR. (B, D, F, H, J and L) The concentration of CCL2, CXCL1 and CXCL8 in the incubation medium was assayed by ELISA. For all data, the fold change was calculated relative to siCONT + IL1B- or siCONT + TNF-transfected cells and data displayed as mean \pm S.E.M. Individual data points represent six independent experiments. ${ }^{*} P \leq 0.05$ (repeated measures one-way ANOVA). 

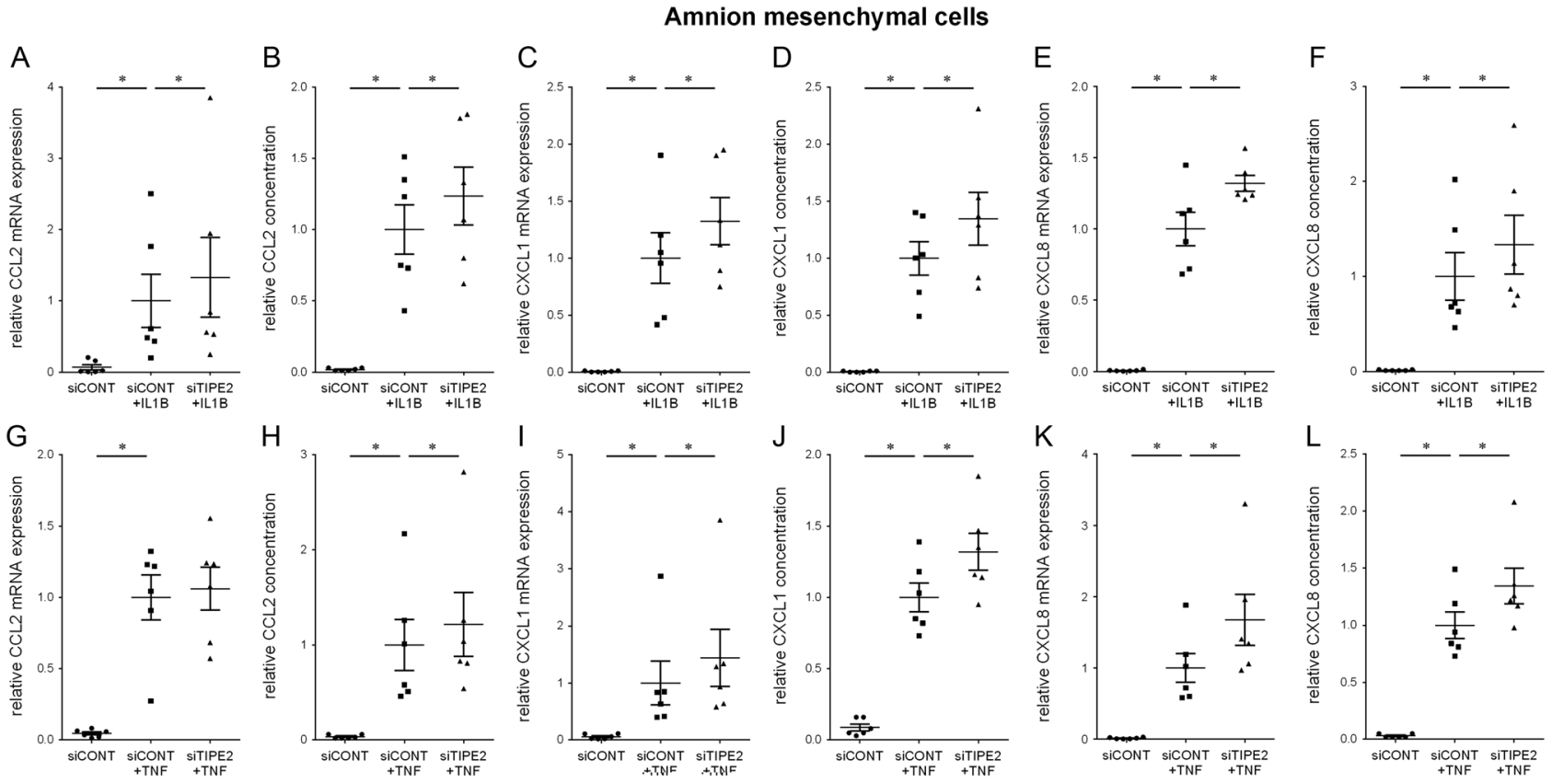

Figure 4 Effect of TIPE2 siRNA transfection on chemokines in amnion mesenchymal cells. Human primary amnion mesenchymal cells were transfected with $25 \mathrm{nM}$ siCONT or $25 \mathrm{nM}$ siTIPE2 and then treated with $1 \mathrm{ng} / \mathrm{mL}$ IL1B or $10 \mathrm{ng} / \mathrm{mL}$ TNF ( $n=6$ patients). (A, C, E, G, I and K) CCL2, CXCL1 and CXCL8 mRNA expression were analyzed by qRT-PCR. (B, D, F, H, J and L) The concentration of CCL2, CXCL1 and CXCL8 in the incubation medium was assayed by ELISA. For all data, the fold change was calculated relative to siCONT+IL1B- or siCONT+TNF-transfected cells and data displayed as mean \pm S.E.M. Individual data points represent six independent experiments. ${ }^{*} P \leq 0.05$ (repeated measures one-way ANOVA).

in Fig. 5. siCONT-transfected cells treated with IL1B showed an expected increase in PTGS2 and PTGFR mRNA expression (Fig. 5A and C), PTGS2 protein expression (Fig. 5B) and $\mathrm{PGF}_{2 \alpha}$ secretion (Fig. 5E) and a decrease in $\mathrm{C} x 43 \mathrm{mRNA}$ expression (Fig. 5D). There was a significant augmentation of IL1B-induced PTGS2 mRNA and protein expression (Fig. 5A and B) and secretion of PGF $2 \alpha$ (Fig. 5E) in siTIPE2 transfected cells. These cells also displayed a significant increase in IL1Binduced Cx43 mRNA expression (Fig. 5D). The effect of siTIPE2 on TNF-induced expression of contractionassociated proteins and prostaglandins is shown in Fig. 5F, G, H and I. There was a significant augmentation of TNF-induced PTGS2 and Cx43 mRNA expression (Fig. 5F and H; PTGS2 protein expression was too low for analysis) and $\mathrm{PGF}_{2 \alpha}$ secretion (Fig. 5I) in siTIPE2 cells. There was no effect of siTIPE2 on TNF-induced PTGFR mRNA expression (Fig. 5G). In addition, there was no effect of siTIPE2 on OXTR mRNA expression (data not shown).

\section{Effect of TIPE2 on the expression of ECM components in human primary myometrial and amnion cells}

Myometrial growth and remodeling during pregnancy depends on increased synthesis of interstitial matrix proteins. In myometrium, there is increased MMP9 mRNA expression in humans (Roh et al. 2000) and fibronectin ( $F N 1$ ), laminin $\beta 2$ (LAMB2) and collagen IV mRNA expression (Shynlova et al. 2004) during labor in rat. Thus, it was also of interest to determine if TIPE2 is involved in their regulation. In siCONT-transfected myometrial cells, there was no effect of IL1B or TNF on FN1 or LAMB2 mRNA expression, while both IL1B and TNF significantly increased MMP9 mRNA expression and the secretion of pro MMP9 (Fig. 6A, B, C, D, E, $\mathrm{F}, \mathrm{G}$ and $\mathrm{H})$. FN1, LAMB2, MMP9 mRNA expression and secretion of pro-MMP9 was further exaggerated in siTIPE2-transfected cells when treated with IL1B or TNF.

MMPs also plays an important role in the degradation of the fetal membranes during labor (Vadillo-Ortega

Table 5 Effect of siTIPE2 on basal mRNA expression and secretion of pro-labor mediators in human primary myometrial cells.

\begin{tabular}{|c|c|c|c|c|c|c|c|c|c|c|c|}
\hline & \multirow[b]{2}{*}{ TNF } & \multirow[b]{2}{*}{ IL1A } & \multirow[b]{2}{*}{ IL1B } & \multicolumn{4}{|c|}{ mRNA expression } & \multicolumn{4}{|c|}{ Secretion } \\
\hline & & & & IL6 & CCL2 & CXCL1 & CXCL8 & IL6 & CCL2 & CXCL1 & CXCL8 \\
\hline SiCONT & $1.0 \pm 0.1$ & $1.0 \pm 0.7$ & $1.0 \pm 0.6$ & $1.0 \pm 0.5$ & $1.0 \pm 0.3$ & $1.0 \pm 0.3$ & $1.0 \pm 0.3$ & $1.0 \pm 0.4$ & $1.0 \pm 0.3$ & $1.0 \pm 0.3$ & $1.0 \pm 0.2$ \\
\hline siTIPE2 & $1.3 \pm 0.5$ & $0.8 \pm 0.5$ & $1.1 \pm 0.6$ & $0.9 \pm 0.4$ & $1.2 \pm 0.3$ & $0.8 \pm 0.1$ & $0.8 \pm 0.2$ & $1.1 \pm 0.5$ & $1.0 \pm 0.3$ & $1.1 \pm 0.3$ & $1.0 \pm 0.2$ \\
\hline
\end{tabular}

For all data, the fold change was calculated relative to siCONT-transfected cells and data displayed as mean \pm S.E.M. 

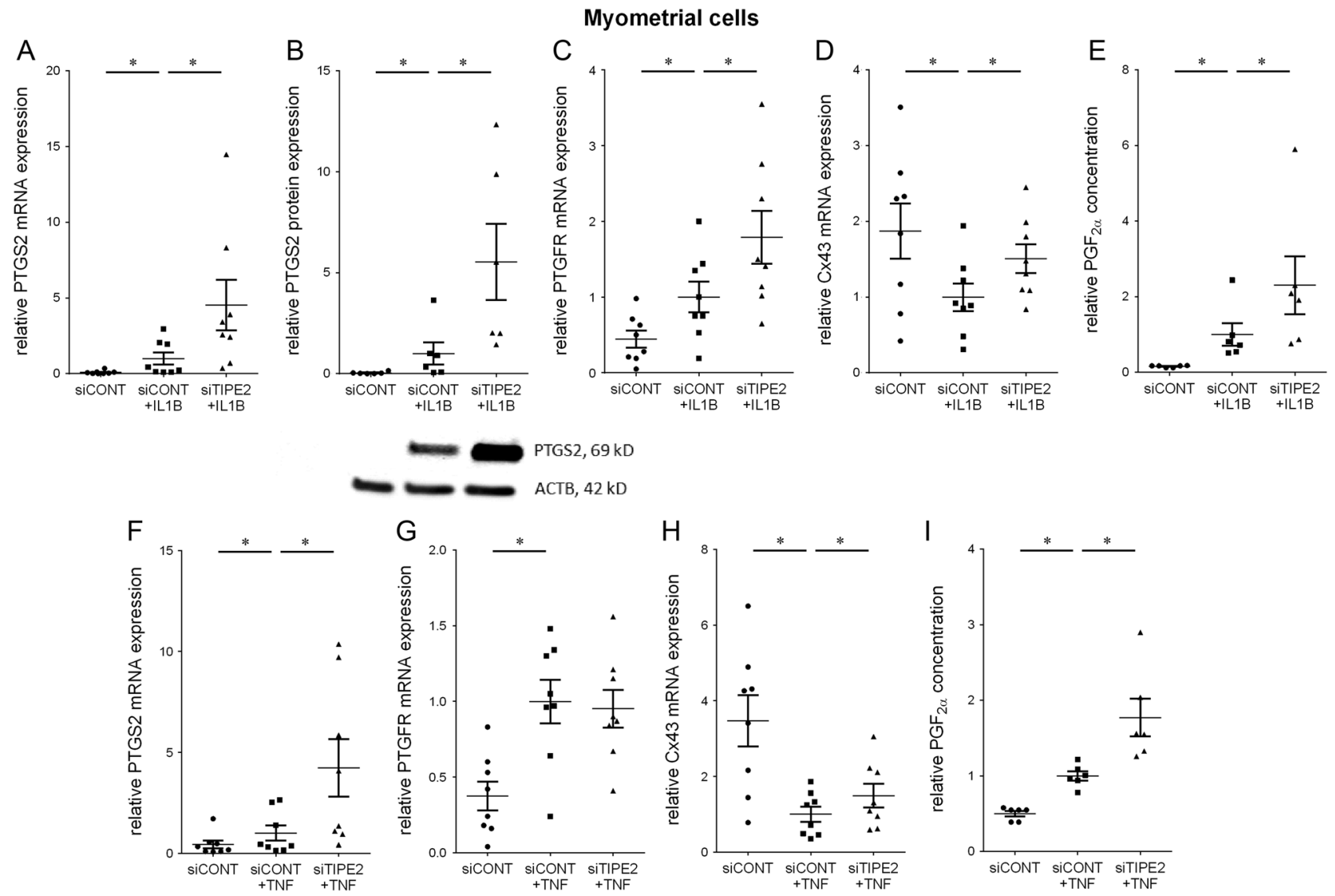

Figure 5 Effect of TIPE2 siRNA transfection on myometrial contraction-associated proteins. Human primary myometrial cells were transfected with $25 \mathrm{nM}$ siCONT or $25 \mathrm{nM}$ siTIPE2 and then treated with (A, B, C, D and E) $1 \mathrm{ng} / \mathrm{mL}$ IL1B or (F, G, H and I) $10 \mathrm{ng} / \mathrm{mL}$ TNF ( $n=6 \mathrm{patients}$ ). (A, C, D, F, G and H) PTGS2, PTGFR and Cx43 mRNA expression was analyzed by qRT-PCR. (B) PTGS2 protein expression was analyzed by Western blotting. A representative Western blot image from one patient is also shown. (E and I) The concentration of PGF ${ }_{2 \alpha}$ in the incubation medium was assayed by ELISA. For all data, the fold change was calculated relative to siCONT + IL1B- or siCONT+TNF-transfected cells and data displayed as mean \pm S.E.M. Individual data points represent six independent experiments. ${ }^{*} P \leq 0.05$ (repeated measures one-way ANOVA).

\& Estrada-Gutierrez 2005). Thus, we examined the effect of siTIPE2 on the expression of MMPs in amnion mesenchymal cells and epithelial cells. In mesenchymal cells, IL1B and TNF treatment significantly increase in MMP1 and MMP8 mRNA expression (Fig. 7A, B, C and D). The effect of siTIPE2 was a significant augmentation of IL1B or TNF induced MMP1 and MMP8 mRNA expression. In epithelial cells, IL1B and TNF increased MMP9 mRNA expression and the secretion of pro MMP9 (Fig. 7E, F, G and H). There was no effect of siTIPE2 on IL1B-induced MMP9 mRNA expression or release of pro-MMP9 (Fig. 7E and F). On the other hand, there was a significant increase in MMP9 mRNA expression and pro-MMP9 secretion in TNF-induced siTIPE2-transfected cells (Fig. 7G and $\mathrm{H}$ ).

\section{Anti-inflammatory actions of TIPE2 are mediated through NF-KB and MAPK signaling pathways}

NF-кB (Lappas et al. 2002, 2003, Lindstrom \& Bennett 2005, Lappas \& Rice 2007) and the MAPK protein
ERK1/2 (Sooranna et al. 2005, Lappas et al. 2007, $2011 b$ ) have been shown to regulate pro-labor mediators in intrauterine tissues. Thus, we wanted to investigate whether TIPE2 regulates pro-inflammatory and prolabor mediators through NF-KB and ERK1/2. To do this, we used selective pharmacological inhibitors of NF-kB and ERK1/2, BAY 11-7082 and U0126, respectively. We also used the polyphenol naringenin, which we have shown to regulate pro-inflammatory and pro-labor mediators via NF-kB (Lim et al. 2013b). As shown in Fig. 8, BAY 11-7082, naringenin and U0126 treatment of siTIPE2-transfected myometrial cells, in the presence of IL1B, significantly reduced the secretion of IL6, CXCL1, CXCL8 and PGF $2 \alpha$ back to levels similar to IL1Btransfected siCONT cells.

\section{Discussion}

The novel findings of this study are that in myometrium, advancing gestation is associated with decreased TIPE2 

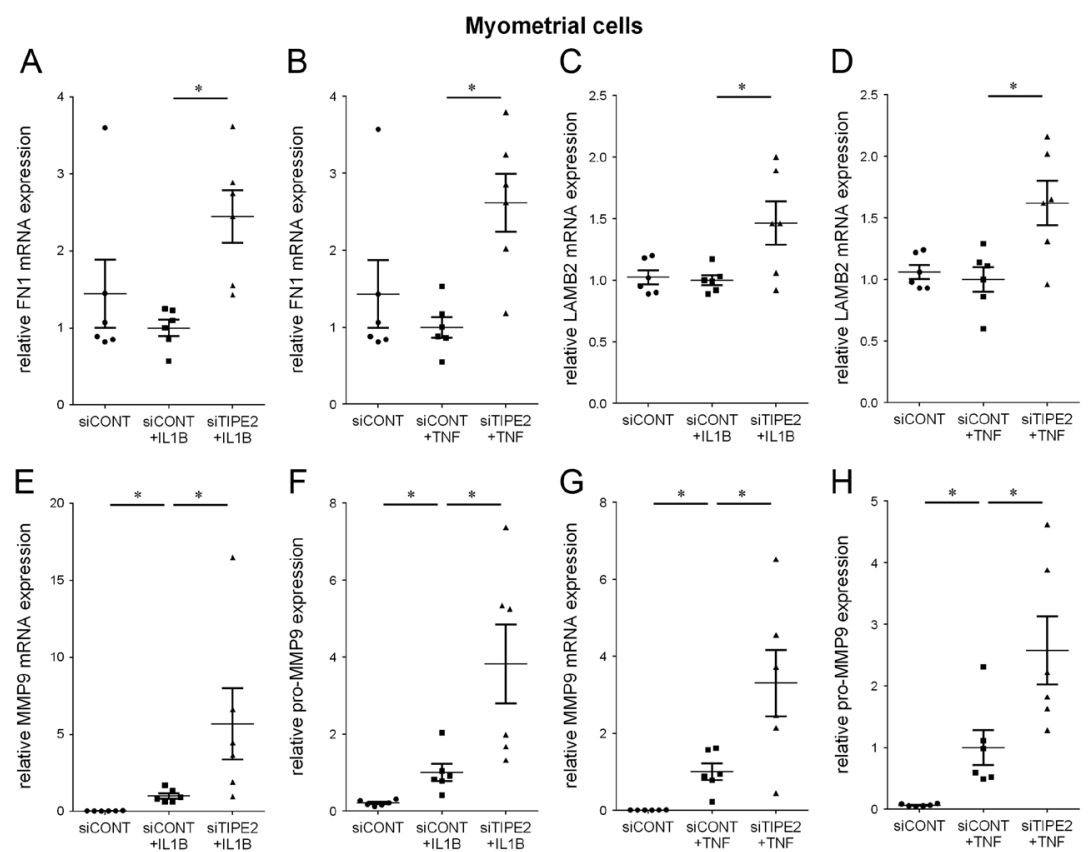

\begin{abstract}
Figure 6 Effect of TIPE2 siRNA transfection on the expression of ECM proteins in myometrial cells. Human primary myometrial cells were transfected with $25 \mathrm{nM}$ siCONT or $25 \mathrm{nM}$ siTIPE2 and then treated with $(\mathrm{A}, \mathrm{C}, \mathrm{E}$ and F) $1 \mathrm{ng} / \mathrm{mL}$ IL $1 \mathrm{~B}$ or (B, D, G and H) $10 \mathrm{ng} / \mathrm{mL}$ TNF ( $n=6$ patients). (A, B, C, D, E and G)FN1, $\angle A M B 2$ and MMP9 mRNA expression was analyzed by qRT-PCR ( $\mathrm{F}$ and $\mathrm{H})$. For all data, the fold change was calculated relative to siCONT + IL1B- or siCONT + TNF-transfected cells and data displayed as mean \pm S.E.M. Individual data points represent six independent experiments. ${ }^{*} P \leq 0.05$ (repeated measures one-way ANOVA).
\end{abstract}

expression. Furthermore, at term, labor is associated with decreased TIPE2 expression in myometrium. In fetal membranes, while there was no difference in TIPE2 expression with advancing gestation, TIPE2 expression was decreased with labor at both term and preterm. In order to elucidate the role of TIPE2 in myometrium and fetal membranes, we performed lossof-function studies. We found that, in the presence of pro-inflammatory stimuli, loss of TIPE2 was associated with a significant augmentation of pro-inflammatory cytokines, chemokines, ECM degrading/remodeling enzymes, contraction-associated proteins and the uterotonic prostaglandin $\mathrm{PGF}_{2 \alpha}$. NF-KB and the MAPK protein ERK1/2 are required for TIPE2 to mediate its antiinflammatory effects as the NF-кB inhibitor BAY 11-7082 and the ERK1/2 inhibitor U0126 significantly inhibited siTIPE2-induced expression of pro-labor mediators.

The finding of decreased TIPE2 mRNA expression at term compared to preterm suggests that the loss of TIPE2 may be involved in the shift of the myometrium from a quiescent into a contractile state in preparation for labor. A number of contraction-associated proteins have been shown to play a role in this process including Cx43 (Chow \& Lye 1994, Sparey et al. 1999, Renthal et al. 2010), PTGS2 (Slater et al. 1999) and PTGFR (BrodtEppley \& Myatt 1999). PGF $_{2 \alpha}$ also plays an important role in myometrial contractility; $\mathrm{PGF}_{2 \alpha}$ levels are increased in the amniotic fluid in late pregnancy (Romero et al. 1996) and intrauterine injection of PGF $_{2 \alpha}$ induces human labor (Lindberg 1977). To assess if TIPE2 is involved in the expression of contraction-associated proteins, human primary myometrial cells were transfected with TIPE2 or control siRNA and then treated with either IL1B or TNF. We found that when compared to control siRNAtransfected cells, Cx43, PTGS2 and PTGFR expression and $\mathrm{PGF}_{2 \alpha}$ release were significantly augmented. These findings suggest that TIPE2 may suppress myometrial contractility by negatively regulating the expression of Cx43 and the biosynthesis and activity of $\mathrm{PGF}_{2 \alpha}$. We also assessed the expression of ECM components involved in the growth and remodeling of the myometrium during pregnancy and labor, namely MMP9, FN1 and LAMB2 (Roh et al. 2000, Shynlova et al. 2004). We found that siTIPE2 increased their expression in myometrial cells suggesting a shift toward a more contractile state. Further functional studies are required to determine the effect of TIPE2 silencing on myometrial contractility and cytoskeleton reorganization.

Pro-inflammatory cytokines, chemokines and ECM proteins have all been shown to be increased during labor in the uterus and fetal membranes (Thomson et al. 1999, Roh et al. 2000, Osman et al. 2003, Shynlova et al. 2004, Bollapragada et al. 2009, Weiner et al. 2010, Singh et al. 2017). At or around the time of labor, leukocytes infiltrate uterine tissues (myometrium, cervix, fetal membranes, decidua), leading to this increased expression of pro-inflammatory cytokines and chemokines. In turn, these cytokines and chemokines regulate the expression of MMPs to facilitate rupture of fetal membranes. Decreased TIPE2 expression in both myometrium and fetal membranes during labor suggests that TIPE2 may be involved in propagating the labor 

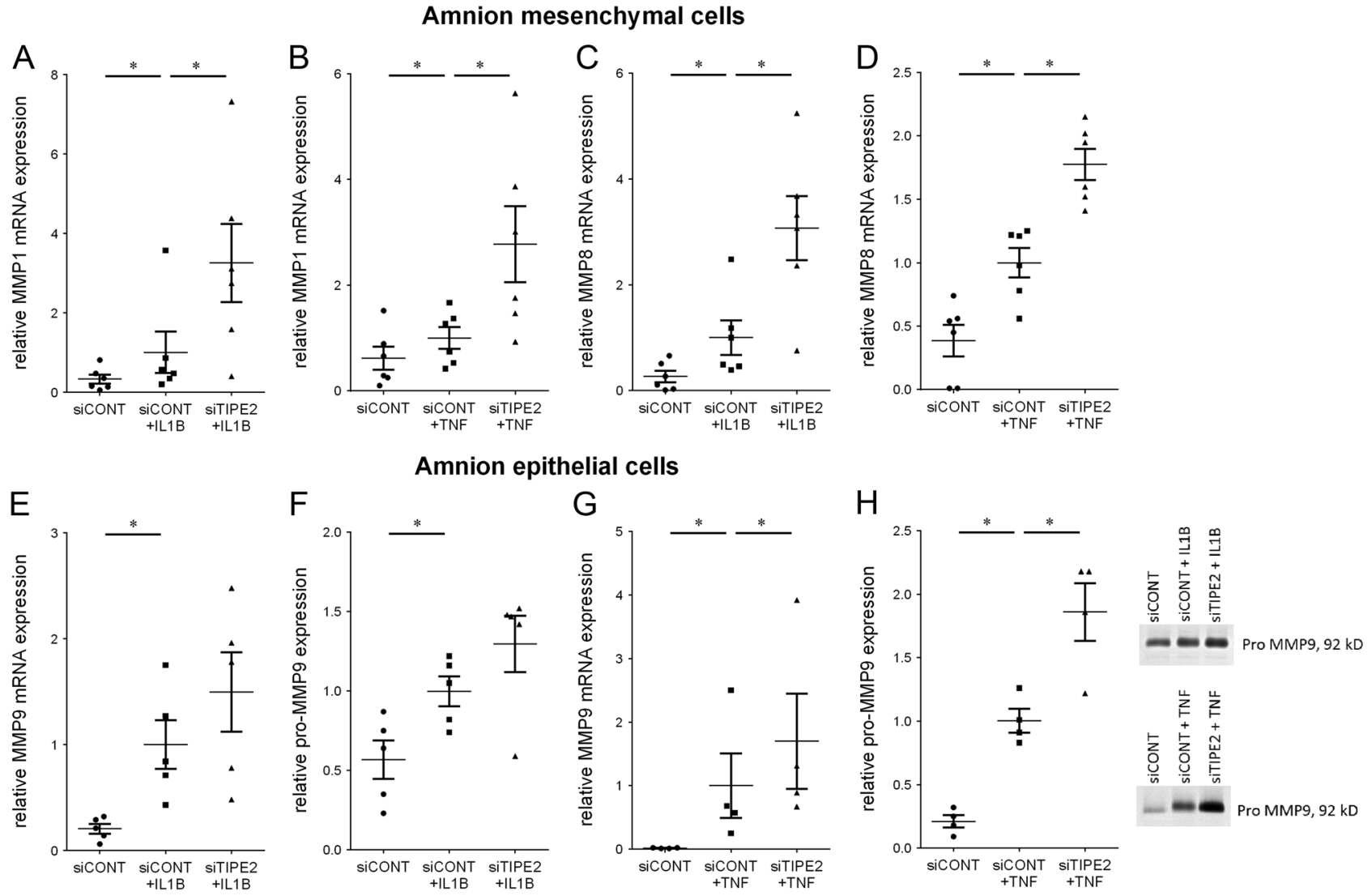

Figure 7 Effect of TIPE2 siRNA transfection on the expression of ECM proteins in amnion cells. Human primary amnion (A, B, C and D) mesenchymal cells or (E, F, G and $\mathrm{H}$ ) epithelial cells were transfected with $25 \mathrm{nM}$ siCONT or $25 \mathrm{nM}$ siTIPE2 and then treated with $1 \mathrm{ng} / \mathrm{mL}$ IL1B or $10 \mathrm{ng} / \mathrm{mL}$ TNF. (A, B, C, D, E and G) MMP1, MMP8 and MMP9 mRNA expression was analyzed by qRT-PCR. (F and H) The concentration of pro MMP9 in the incubation medium was assayed by zymography. Representative zymography image from one patient is also shown. For all data, the fold change was calculated relative to siCONT + IL1B- or siCONT+TNF-transfected cells and data displayed as mean \pm S.E.M. Individual data points represent 5-6 independent experiments. ${ }^{*} P \leq 0.05$ (repeated-measures one-way ANOVA).

processes. In order to assess this, we examined the effect of siTIPE2 on the expression of pro-labor mediators. We found that in primary myometrial and amnion cells deficient in TIPE2, there was a significant augmentation of IL1B or TNF-induced pro-inflammatory cytokines (IL1A, IL1B, IL6), chemokines (CCL2, CXCL1, CXCL8) and MMPs. Interestingly, in myometrial cells and amnion epithelial cells, and in contrast to amnion mesenchymal cells, CCL2 mRNA expression and secretion was not regulated by TIPE2. Likewise, TIPE2 regulates MMP9 mRNA expression and secretion of pro MMP9 induced by TNF not IL1B. This suggests that TIPE2 regulation of pro-inflammatory mediators is cell and stimulus specific.

TIPE2 has been found to inhibit NF-KB and the MAPK protein ERK (Sun et al. 2008, Lou et al. 2013, Goldsmith \& Chen 2017, Zhang et al. 2017, Lin et al. 2018). These signaling pathways have been shown to play important roles in regulating pro-inflammatory and pro-labor mediators in human myometrium and fetal membranes (Lappas et al. 2002, 2003, 2007, 2011b, Lindstrom \& Bennett 2005, Sooranna et al. 2005,
Lappas \& Rice 2007). Thus, we sought to determine if NF- $\mathrm{KB}$ and ERK are involved in the upregulation of prolabor mediators observed in TIPE2-deficient cells. This was assessed by determining the effect of inhibitors of NF-kB (pharmacological inhibitor BAY 11-7082 and polyphenol naringenin) and ERK1/2 (pharmacological inhibitor U0126) activation on IL1B-induced pro-labor mediators in siTIPE2-transfected myometrial cells. We found that in siTIPE2-transfected cells, treatment with BAY 11-7082, naringenin or U0126 significantly reduced IL-1B-induced secretion of pro-labor mediators. Collectively, these findings suggest that TIPE2 acts as a negative regulator of pro-labor mediators by interfering with NF-KB and ERK $1 / 2$.

A limitation of this study is that the temporal and labor-associated changes observed in TIPE2 mRNA expression could not be validated at the protein level. We tested numerous TIPE2 commercial antibodies but were unable to confirm specificity. Further studies examining the regional localization of TIPE2 in fetal membranes (i.e. site over the cervix prone to rupture 

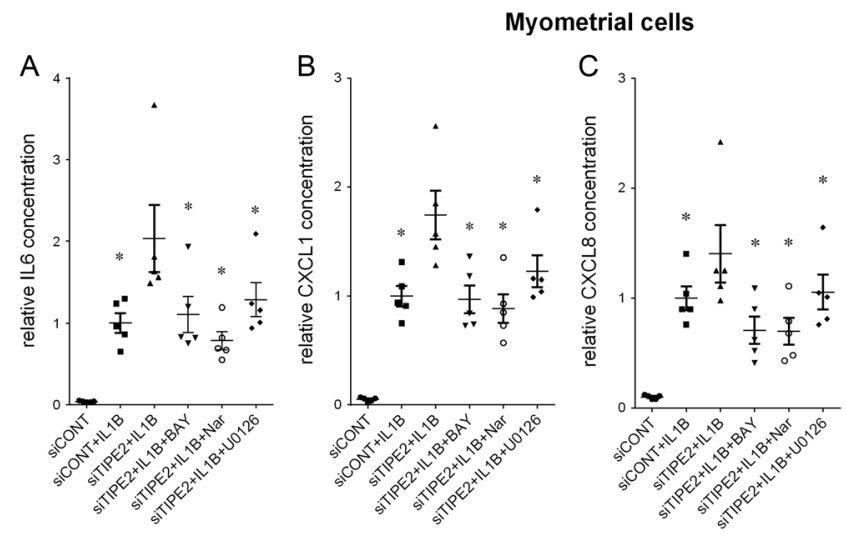

versus distal areas) would shed further light on the role of TIPE2 in fetal membrane rupture. In addition, due to laboratory restrictions, we were unable to confirm our siRNA results using overexpression of TIPE2. Finally, for the expression studies, we used fetal membranes overlying the cervix. This site is known to be inflamed due to infiltrating immune cells (Marcellin et al. 2017) and thus any changes in this area may not truly reflective of fetal membrane physiology away from cervix and on top of placental bed.

In summary, we have identified a novel role of TIPE2 in myometrium and fetal membranes. TIPE2 is lower in myometrium at term gestation and further decreased during labor suggesting a possible role in the transition of the myometrium from a quiescent to contractile state. In support, siRNA-knockdown experiments demonstrated that TIPE2 regulates contractionassociated proteins (Cx43, PTGS2, PTGFR) and the uterotonic prostaglandin PGF $_{2 \alpha}$. TIPE2 expression was also lower in myometrium and fetal membranes after active labor onset at term and/or preterm, which points to a potential mechanistic role for TIPE2 in human labor and delivery. This hypothesis is supported by our in vitro studies, whereby inhibition of TIPE2 in primary cells isolated from myometrium and amnion demonstrated that TIPE2 is a negative regulator of inflammation induced expression of mediators involved in propagating labor including pro-inflammatory cytokines, chemokines and ECM remodeling enzymes. Our conclusions are limited to mRNA expression studies and siRNA knockdown in vitro studies in primary myometrial amnion cells. Further studies are required to examine the potential role of TIPE2 in preterm birth.

\section{Declaration of interest}

The authors declare that there is no conflict of interest that could be perceived as prejudicing the impartiality of the research reported.
Figure 8 Effect of NF-kB and MAPK inhibitors on TIPE2 siRNA transfection induced pro-labor mediators in myometrial cells. Human primary myometrial cells were transfected with $25 \mathrm{nM}$ siCONT or $25 \mathrm{nM}$ siTIPE2 and then treated with $1 \mathrm{ng} / \mathrm{mL}$ IL1B in the absence or presence of 10 $\mu \mathrm{M}$ BAY 11-7082 (BAY), $400 \mu \mathrm{M}$ naringenin (nar) or $5 \mu \mathrm{M} \cup 0126$ for an additional $20 \mathrm{~h}$ ( $n=5$ patients). (A, B, C and D) The concentration of IL-6, CXCL1, CXCL8 and $\mathrm{PGF}_{2 \alpha}$ in the incubation medium was assayed by ELISA. For all data, the fold change was calculated relative to siCONT + IL1B or siCONT+TNF transfected cells and data displayed as mean \pm S.E.M. Individual data points represent five independent experiments. ${ }^{*} P \leq 0.05$ vs siTIPE2 + IL1B-transfected cells (repeated-measures one-way ANOVA).

\section{Funding}

Associate Professor Martha Lappas is supported by a Research Fellowship from the Department of Obstetrics and Gynaecology (University of Melbourne) and a Faculty Fellowship from the University of Melbourne. Funding for this study was provided by Norman Beischer Medical Research Foundation, the University of Melbourne and the Mercy Research Foundation.

\section{Author contribution statement}

$M L$ designed the study, performed some experiments, analyzed the data and wrote the manuscript. $\mathrm{R} L$ performed experiments and wrote the manuscript.

\section{Acknowledgements}

The following are gratefully acknowledged: Clinical Research Midwives Genevieve Christophers, Gabrielle Pell and Rachel Murdoch for sample collection and the Obstetrics and Midwifery staff of the Mercy Hospital for Women for their co-operation.

\section{References}

Blencowe H, Cousens S, Chou D, Oestergaard M, Say L, Moller AB, Kinney M, Lawn J \& Born Too Soon Preterm Birth Action Group 2013 Born too soon: the global epidemiology of 15 million preterm births. Reproductive Health $\mathbf{1 0}$ (Supplement 1) S2. (https://doi. org/10.1186/1742-4755-10-S1-S2)

Bollapragada S, Youssef R, Jordan F, Greer I, Norman J \& Nelson S 2009 Term labor is associated with a core inflammatory response in human fetal membranes, myometrium, and cervix. American Journal of Obstetrics and Gynecology 200 104.e101-104.e111. (https://doi. org/10.1016/j.ajog.2008.08.032)

Brodt-Eppley J \& Myatt L 1999 Prostaglandin receptors in lower segment myometrium during gestation and labor. Obstetrics and Gynecology 93 89-93. (https://doi.org/10.1016/S0029-7844(98)00378-0)

Chow L \& Lye SJ 1994 Expression of the gap junction protein connexin-43 is increased in the human myometrium toward term and with the onset of labor. American Journal of Obstetrics and Gynecology 170 788-795. (https://doi.org/10.1016/S0002-9378(94)70284-5)

Christiaens I, Zaragoza DB, Guilbert L, Robertson SA, Mitchell BF \& Olson DM 2008 Inflammatory processes in preterm and term 
parturition. Journal of Reproductive Immunology 79 50-57. (https://doi. org/10.1016/j.jri.2008.04.002)

Freundt EC, Bidere N \& Lenardo MJ 2008 A different TIPE of immune homeostasis. Cell $133 \quad 401-402$. (https://doi.org/10.1016/j. cell.2008.04.017)

Goldsmith JR, Fayngerts S \& Chen YH 2017 Regulation of inflammation and tumorigenesis by the TIPE family of phospholipid transfer proteins. Cellular and Molecular Immunology 14 482-487. (https://doi. org/10.1038/cmi.2017.4)

Gus-Brautbar Y, Johnson D, Zhang L, Sun H, Wang P, Zhang S, Zhang L \& Chen YH 2012 The anti-inflammatory TIPE2 is an inhibitor of the oncogenic Ras. Molecular Cell 45 610-618. (https://doi.org/10.1016/j. molcel.2012.01.006)

Lappas M 2017 The IL-1beta signalling pathway and its role in regulating pro-inflammatory and pro-labour mediators in human primary myometrial cells. Reproductive Biology 17 333-340. (https://doi. org/10.1016/j.repbio.2017.09.006)

Lappas M, Mitton A, Lim R, Barker G, Riley C \& Permezel M 2011 a SIRT1 is a novel regulator of key pathways of human labor. Biology of Reproduction 84 167-178. (https://doi.org/10.1095/biolreprod.110.086983)

Lappas M, Permezel M, Georgiou HM \& Rice GE 2002 Nuclear factor kappa $B$ regulation of proinflammatory cytokines in human gestational tissues in vitro. Biology of Reproduction 67 668-673. (https://doi. org/10.1095/biolreprod67.2.668)

Lappas M, Permezel M \& Rice GE 2003 N-acetyl-cysteine inhibits phospholipid metabolism, proinflammatory cytokine release, protease activity, and nuclear factor-kappaB deoxyribonucleic acid-binding activity in human fetal membranes in vitro. Journal of Clinical Endocrinology and Metabolism 88 1723-1729. (https://doi.org/10.1210/ jc.2002-021677)

Lappas M, Permezel M \& Rice GE 2007 Mitogen-activated protein kinase proteins regulate LPS-stimulated release of pro-inflammatory cytokines and prostaglandins from human gestational tissues. Placenta $\mathbf{2 8}$ 936-945. (https://doi.org/10.1016/j.placenta.2007.02.009)

Lappas M \& Rice GE 2007 The role and regulation of the nuclear factor kappa B signalling pathway in human labour. Placenta 28 543-556. (https://doi.org/10.1016/j.placenta.2006.05.011)

Lappas M, Riley C, Lim R, Barker G, Rice GE, Menon R \& Permezel M $2011 b$ MAPK and AP-1 proteins are increased in term pre-labour fetal membranes overlying the cervix: regulation of enzymes involved in the degradation of fetal membranes. Placenta 32 1016-1025. (https://doi. org/10.1016/j.placenta.2011.09.011)

Li D, Song L, Fan Y, Li X, Li Y, Chen J, Zhu F, Guo C, Shi Y \& Zhang L 2009 Down-regulation of TIPE2 mRNA expression in peripheral blood mononuclear cells from patients with systemic lupus erythematosus. Clinical Immunology $133 \quad 422-427 . \quad$ (https://doi.org/10.1016/j. clim.2009.08.014)

Lim R, Barker G \& Lappas M 2013a A novel role for FOXO3 in human labor: increased expression in laboring myometrium, and regulation of proinflammatory and prolabor mediators in pregnant human myometrial cells. Biology of Reproduction 88 156. (https://doi.org/10.1095/ biolreprod.113.108126)

Lim R, Barker G \& Lappas M 2013b SIRT6 is decreased with preterm labor and regulates key terminal effector pathways of human labor in fetal membranes. Biology of Reproduction 88 17. (https://doi.org/10.1095/ biolreprod.112.105163)

Lim R, Barker G \& Lappas M 2014 TREM-1 expression is increased in human placentas from severe early-onset preeclamptic pregnancies where it may be involved in syncytialization. Reproductive Sciences $\mathbf{2 1}$ 562-572. (https://doi.org/10.1177/1933719113503406)

Lim R, Barker G \& Lappas M 2017 TRADD, TRAF2, RIP1 and TAK1 are required for TNF-alpha-induced pro-labour mediators in human primary myometrial cells. American Journal of Reproductive Immunology 78. (https://doi.org/10.1111/aji.12664)

Lim R, Barker G \& Lappas M 2018 PARK7 regulates inflammation-induced pro-labour mediators in myometrial and amnion cells. Reproduction 155 207-218. (https://doi.org/10.1530/REP-17-0604)

Lin Z, Liu W, Xiao C, Fan Y, Zhuang G \& Qi Z 2018 TIPE2 inhibits GC via regulation of cell proliferation, apoptosis and inflammation. Oncology Reports 40 1307-1316. (https://doi.org/10.3892/or.2018.6576)
Lindberg B 1977 The induction of labour by the intravenous infusion of prostaglandin F2alpha. Prostaglandins 14 993-1004. (https://doi. org/10.1016/0090-6980(77)90314-8)

Lindstrom TM \& Bennett PR 2005 The role of nuclear factor kappa B in human labour. Reproduction 130 569-581. (https://doi.org/10.1530/ rep.1.00197)

Lou Y, Liu S, Zhang C, Zhang G, Li J, Ni M, An G, Dong M, Liu X, Zhu $\mathbf{F}$ et al. 2013 Enhanced atherosclerosis in TIPE2-deficient mice is associated with increased macrophage responses to oxidized lowdensity lipoprotein. Journal of Immunology 191 4849-4857. (https://doi. org/10.4049/jimmunol.1300053)

Lou Y, Sun H, Morrissey S, Porturas T, Liu S, Hua X \& Chen YH 2014 Critical roles of TIPE2 protein in murine experimental colitis. Journal of Immunology 193 1064-1070. (https://doi.org/10.4049/jimmunol.1400415)

Ma Y, Liu X, Wei Z, Wang X, Wang Z, Zhong W, Li Y, Zhu F, Guo C, Zhang L et al. 2013 The expression and significance of TIPE2 in peripheral blood mononuclear cells from asthmatic children. Scandinavian Journal of Immunology 78 523-528. (https://doi.org/10.1111/sji.12110)

Marcellin L, Schmitz T, Messaoudene M, Chader D, Parizot C, Jacques S, Delaire J, Gogusev J, Schmitt A, Lesaffre C et al. 2017 Immune modifications in fetal membranes overlying the cervix precede parturition in humans. Journal of Immunology 198 1345-1356. (https:// doi.org/10.4049/jimmunol.1601482)

Moore RM, Novak JB, Kumar D, Mansour JM, Mercer BM \& Moore JJ 2009 Alpha-lipoic acid inhibits tumor necrosis factor-induced remodeling and weakening of human fetal membranes. Biology of Reproduction 80 781-787. (https://doi.org/10.1095/biolreprod.108.073205)

Osman I, Young A, Ledingham MA, Thomson AJ, Jordan F, Greer IA \& Norman JE 2003 Leukocyte density and pro-inflammatory cytokine expression in human fetal membranes, decidua, cervix and myometrium before and during labour at term. Molecular Human Reproduction 9 41-45. (https://doi.org/10.1093/humrep/gag001)

Renthal NE, Chen CC, Williams KC, Gerard RD, Prange-Kiel J \& Mendelson CR 2010 miR-200 family and targets, ZEB1 and ZEB2, modulate uterine quiescence and contractility during pregnancy and labor. PNAS 107 20828-20833. (https://doi.org/10.1073/ pnas.1008301107)

Roh CR, Oh WJ, Yoon BK \& Lee JH 2000 Up-regulation of matrix metalloproteinase-9 in human myometrium during labour: a cytokinemediated process in uterine smooth muscle cells. Molecular Human Reproduction 6 96-102. (https://doi.org/10.1093/molehr/6.1.960)

Romero R, Mazor M \& Tartakovsky B 1991 Systemic administration of interleukin-1 induces preterm parturition in mice. American Journal of Obstetrics and Gynecology 165 969-971. (https://doi.org/10.1016/00029378(91)90450-6)

Romero R, Munoz H, Gomez R, Parra M, Polanco M, Valverde V, Hasbun J, Garrido J, Ghezzi F, Mazor M et al. 1996 Increase in prostaglandin bioavailability precedes the onset of human parturition. Prostaglandins, Leukotrienes, and Essential Fatty Acids 54 187-191. (https://doi. org/10.1016/S0952-3278(96)90015-0)

Sadowsky DW, Adams KM, Gravett MG, Witkin SS \& Novy MJ 2006 Preterm labor is induced by intraamniotic infusions of interleukin-1beta and tumor necrosis factor-alpha but not by interleukin- 6 or interleukin-8 in a nonhuman primate model. American Journal of Obstetrics and Gynecology 195 1578-1589. (https://doi.org/10.1016/j.ajog.2006.06.072)

Shynlova O, Lee YH, Srikhajon K \& Lye SJ 2013 Physiologic uterine inflammation and labor onset: integration of endocrine and mechanical signals. Reproductive Sciences 20 154-167. (https://doi. org/10.1177/1933719112446084)

Shynlova O, Mitchell JA, Tsampalieros A, Langille BL \& Lye SJ 2004 Progesterone and gravidity differentially regulate expression of extracellular matrix components in the pregnant rat myometrium. Biology of Reproduction 70 986-992. (https://doi.org/10.1095/ biolreprod.103.023648)

Singh N, Herbert B, Sooranna GR, Orsi NM, Edey L, Dasgupta T, Sooranna SR, Yellon SM \& Johnson MR 2017 Is myometrial inflammation a cause or a consequence of term human labour? Journal of Endocrinology 235 69-83. (https://doi.org/10.1530/JOE-17-0318)

Slater DM, Dennes WJ, Campa JS, Poston L \& Bennett PR 1999 Expression of cyclo-oxygenase types- 1 and -2 in human myometrium throughout 
pregnancy. Molecular Human Reproduction 5 880-884. (https://doi. org/10.1093/molehr/5.9.880)

Sooranna SR, Engineer N, Loudon JA, Terzidou V, Bennett PR \& Johnson MR 2005 The mitogen-activated protein kinase dependent expression of prostaglandin $\mathrm{H}$ synthase-2 and interleukin-8 messenger ribonucleic acid by myometrial cells: the differential effect of stretch and interleukin1 $\beta$. Journal of Clinical Endocrinology and Metabolism 90 3517-3527. (https://doi.org/10.1210/jc.2004-1390)

Sparey C, Robson SC, Bailey J, Lyall F \& Europe-Finner GN 1999 The differential expression of myometrial connexin-43, cyclooxygenase-1 and -2 , and Gs alpha proteins in the upper and lower segments of the human uterus during pregnancy and labor. Journal of Clinical Endocrinology and Metabolism 84 1705-1710. (https://doi.org/10.1210/ jcem.84.5.5644)

Sun H, Gong S, Carmody RJ, Hilliard A, Li L, Sun J, Kong L, Xu L, Hilliard B, Hu S et al. 2008 TIPE2, a negative regulator of innate and adaptive immunity that maintains immune homeostasis. Cell 133 415-426. (https://doi.org/10.1016/j.cell.2008.03.026)

Sun H, Zhuang G, Chai L, Wang Z, Johnson D, Ma Y \& Chen YH 2012 TIPE2 controls innate immunity to RNA by targeting the phosphatidylinositol 3-kinase-Rac pathway. Journal of Immunology 189 2768-2773. (https:// doi.org/10.4049/jimmunol.1103477)

Sun X, Chen L \& Yan W 2017a TIPE2 inhibits the expression of asthmarelated inflammatory factors in hyperstretched bronchial epithelial cells through the Wnt/beta-catenin pathway. Inflammation 40 770-777. (https://doi.org/10.1007/s10753-017-0521-9)

Sun Y, Wang X, Li Y, Sun H, Wan L, Wang X, Zhang L, Fang Z \& Wei Z $2017 b$ The decreased expression of TIPE2 protein in the decidua of patients with missed abortion and possible significance. Reproductive Biology and Endocrinology 15 68. (https://doi.org/10.1186/s12958-0170285-y)

Suo LG, Cui YY, Bai Y \& Qin XJ 2016 Anti-inflammatory TIPE2 inhibits angiogenic VEGF in retinal pigment epithelium. Molecular Immunology 73 46-52. (https://doi.org/10.1016/j.molimm.2016.03.013)

Thomson AJ, Telfer JF, Young A, Campbell S, Stewart CJ, Cameron IT, Greer IA \& Norman JE 1999 Leukocytes infiltrate the myometrium during human parturition: further evidence that labour is an inflammatory process. Human Reproduction 14 229-236. (https://doi.org/10.1093/ humrep/14.1.229)
Vadillo-Ortega F \& Estrada-Gutierrez G 2005 Role of matrix metalloproteinases in preterm labour. BJOG 112 (Supplement 1) 19-22. (https://doi.org/10.1111/j.1471-0528.2005.00579.x)

Weiner CP, Mason CW, Dong Y, Buhimschi IA, Swaan PW \& Buhimschi CS 2010 Human effector/initiator gene sets that regulate myometrial contractility during term and preterm labor. American Journal of Obstetrics and Gynecology 202 474.e1-474.e20. (https://doi. org/10.1016/j.ajog.2010.02.034)

Xi W, Hu Y, Liu Y, Zhang J, Wang L, Lou Y, Qu Z, Cui J, Zhang G, Liang X et al. 2011 Roles of TIPE2 in hepatitis B virus-induced hepatic inflammation in humans and mice. Molecular Immunology $\mathbf{4 8}$ 1203-1208. (https://doi.org/10.1016/j.molimm.2011.03.002)

Zhang L, Shi Y, Wang Y, Zhu F, Wang Q, Ma C, Chen YH \& Zhang L 2011 The unique expression profile of human TIPE2 suggests new functions beyond its role in immune regulation. Molecular Immunology $\mathbf{4 8}$ 1209-1215. (https://doi.org/10.1016/j.molimm.2011.03.001)

Zhang S, Zhang Y, Wei X, Zhen J, Wang Z, Li M, Miao W, Ding H, Du P, Zhang W et al. 2010 Expression and regulation of a novel identified TNFAIP8 family is associated with diabetic nephropathy. Biochimica and Biophysica Acta 1802 1078-1086. (https://doi.org/10.1016/j. bbadis.2010.08.003)

Zhang Y, Mei S, Zhou Y, Yang D, Pan T, Chen Z \& Wang Q 2017 TIPE2 negatively regulates mycoplasma pneumonia-triggered immune response via MAPK signaling pathway. Scientific Reports 713319. (https://doi.org/10.1038/s41598-017-13825-y)

Zhang Y, Shao Z, Zhang X, Jia X, Xia Y, Zhang Y, Xin N, Guo M, Chen J, Zheng $\mathbf{S}$ et al. 2015 TIPE2 play a negative role in TLR4-mediated utoimmune $\mathrm{T}$ helper 17 cell responses in patients with myasthenia gravis. Journal of Neuroimmune Pharmacology 10 635-644. (https://doi. org/10.1007/s11481-015-9638-5)

Received 11 February 2019

First decision 11 March 2019

Revised manuscript received 8 April 2019

Accepted 25 April 2019 